\title{
Žemaičių bajorai žemės teisme XVI a. pabaigoje (trumpa buvusių ir esamy̨ Žemaitijos žemès teismų knygų apžvalga)
}

\author{
DARIUS VILIMAS \\ Lietuvos istorijos institutas, Kražiu g. 5, LT-01108 Vilnius \\ El. paštas: dariusvilimas@hotmail.com
}

\begin{abstract}
LDK pavietų žemės teismų knygos yra menkai ištirtos. Tyrimo tikslas ir uždaviniai - išnagrinèti XX a. pradžioje aprašytų ir dabar išlikusių Žemaitijos žemès teismų knygų santykị; taip pat ištirti kai kurių LDK pavietų žemès teismų knygų sandarą ir nustatyti jų notarinių ir procesinių dalių santykị. Straipsnyje nagrinėjamas rankraštinių Žemaitijos žemès teismų knygų pobūdis, formuluojama sisteminė jų tyrimo galimybè.
\end{abstract}

Raktažodžiai: LDK žemės teismų knygų sandara, Žemaitijos žemės teismų rankraštinès knygos, Ivanas Sprogis, Antrasis LDK Statutas, LDK bajorija

\section{ISTORINIS IVYKIŲ KONTEKSTAS}

Lietuvos Didžiosios Kunigaikštystès pavietų žemès teismų įkūrimas buvo gana ilgas ir sudètingas, prasidèjęs dar XVI a. 4-ajame dešimtmetyje, kai Pirmajame Lietuvos Statute $1529 \mathrm{~m}$. bajorijai buvo numatyta galimybè dalyvauti regioninių didžiojo kunigaikščio vietininkų teismų darbe. Nuo to amžiaus 5-ojo dešimtmečio pradžios kai kuriuose valstybès administraciniuose centruose veikè Statute numatyti vadinamieji „žemès teismai“, iš valdovo vietininkų teismo pamažu tapę parinktųjų teisejjų teismu. Pradètos reguliariai vesti tų teismų knygos rodo, kad iš esmès senasis vadinamasis žemés teismas (iki Antrojo Lietuvos Statuto priemimo) buvo pilies teismo sinonimas, o pats teismo pavadinimas tada dar nebuvo nusistovejęs. Tačiau bajorija tuo jau nesitenkino. Jie turejjo sektiną Lenkijos bajorų teismų pavyzdi - ten jau senokai veikè nepriklausomas žemès teismas. Dar daugiau - tokie teismai XVI a. pirmojoje puseje buvo įkurti formaliai LDK priklausančioje Palenkès vaivadijoje, kurioje veikẻ lenkų teisè ir skirtingi nei likusioje LDK teritorijoje teismai. Brendo esminè teismo sistemos reforma, sutapusi su kitomis to meto valstybinemis reformomis.

Antrojoje XVI a. pusėje Lietuvos Didžioji Kunigaikštystė įžengè ị reformų epochą. Pradètos valakų reformos tikslas buvo padidinti žemévaldos našumą ir pajamingumą. Kiek vèliau reikejjo reformuoti ir valstybès administraciją, teismą bei savivaldos struktūrą. Tikroji žemès teismo istorija prasideda nuo $1564 \mathrm{~m}$. Bielsko privilegijos, kuri teismo atžvilgiu sulygino visos bajorijos luomo atstovus ir leido pradèti teismo reformą. Po pusantrų metų priimtas ir ịsigaliojęs Antrasis Lietuvos Statutas (LS) jau patvirtino pakitusią teismų sandarą, be didesnių korekcijų egzistavusią du šimtmečius. 
Ką iš teismų reformos laimejjo paprasti bajorai? Kiekviename pavieto ar žemės centre ịsteigti bajoriškieji žemės ir pakamario teismai. Dar buvo ir pilies teismai, tačiau jie liko valdovo administracijos žinioje ir nuo žemès teismo skyrèsi tuo, kad pilies teismo pareigūnai būdavo skiriami vaivados, o jam paliktos spręsti tik kriminalinės bylos. Teismas priartejo prie kiekvieno, net paprasto bajoro, kuris žinojo, kad formaliai jis galès teistis net ir su didiku. Kiekvienas juridinis bajoro veiksmas ar finansinè operacija galèjo būti santykinai greitai užfiksuotas pilies (jie dirbo kas mènesị po dvi savaites) arba žemės teisme. Kadangi renkamas žemès teismas pagal prestižą buvo aukščiau už skiriamų pareigūnų pilies teismą, labai dažnai iš pilies teismo knygų ị žemès būdavo peraktuojami ịvairūs notariniai ịrašai arba vaznių pareiškimai, nes žemės teismas dirbo tik tris sesijas per metus. Kiekviename teisme buvo teismo pareigūnų skrynioje saugomos teismo knygos, kuriose buvo galima įrašyti savo dokumentus nesibaiminant, kad vieno ar kito juridinio akto originalas gali sudegti gaisre - išrašai iš teismo knygų turejo tokią pačią galią kaip ir jų originalai. Taigi teismų reforma ir jų kompetencijos atskyrimas - žemès teismui liko civilinès, pilies teismui - kriminalinès bylos, o pakamario - valdų ribų ginčai - įvedè daug daugiau tvarkos i teisès dalykus. Bajoras žinojo, kada ir kur dirbs vienas ar kitas pavieto teismas. Jis galejjo tikètis ne tik greitesnio teisingumo įvykdymo ar saugesnio sau vertingų dokumentų kopijų peraktavimo. Palengva keitėsi ir paties bajoro mąstysena - šalia pavietų seimelių žemès teismai tapo pagrindine vieta, kur viešojoje erdveje būdavo sprendžiami bajorų tarpusavio ginčai, tvirtinamos jų atliktos finansinès operacijos ar kiti jiems svarbūs dalykai. Net tokie mums keistai atrodantys dalykai, kaip paprastas išplūdimas susitikus gatvèje, nenoras atiduoti jau pažadètą dukrą už vyro ar smulkus chuliganizmas, būdavo skrupulingai fiksuojami. Lygiai taip pat skrupulingai būdavo fiksuojama ne tik teisminio ginčo eiga, bet ir susitaikymas arba teismo nuosprendis. LDK bajorai žemės teismuose igyvendino savo seną svajonę - teismo nepriklausomybès nuo didžiojo kunigaikščio ir didikų vietininkų principą. Kartu tokių teismų ịkūrimas ir darbas buvo labai vertinga teisinès kultūros lavinimosi mokykla. Žemès teismo knygos - neịkainojamos vertès bajorų gyvenimo teisminès briaunos atspindys. Jos mums yra dvigubai vertingesnès dar ir todèl, kad, be juridinių-procesinių dalykų, jose fiksuojama ir daugybė notarinių ar šiaip gyvenimiškos kasdienybès faktų.

\section{TYRIMO SCHEMA}

Tiriant pavietų žemès teismų knygų turinị, naudotasi jau taikyta ir kiek išskleista tyrimo schema. Visi tirtų žemės teismo knygų ịrašai padalyti ị du didelius blokus - tai notariniai ir juridiniai-procesiniai įrašai. Kadangi dažnai sunku nubrèžti ribą tarp notarinių ir juridiniųprocesinių įrašų, stengtasi pabrèžti skirtumą tarp tų dokumentų, kurie buvo aktuoti teismo knygose be jokių tarpininkų, ir tarp tų, kurie įrašyti per pavieto teismo pareigūnus. Taigi pirmuoju atveju kalbama apie grynaji notariatą, kuriame žemès teismas funkcionuoja ne kaip teismo, o kaip notarinė ịstaiga. Kiti atvejai yra panašūs, tačiau jau su teismo tarpininkais, todèl jie priskiriami antrajam ịrašų tipui. Pavyzdžiui, tiesioginis ịvedimas $\mathfrak{i}$ parduotą ar įkeistą ir pan. valdą įrašant tai be tarpininkų bus notarinis įrašas, o tas pats veiksmas, fiksuotas vaznio ir su juo buvusių bajorų liudininkų, jau priklausys antrajai įrašu grupei. Lygiai taip pat pavieto vazniai, igalioti aktuoti koki notarinị savo bičiulių ịrašą, priklausys pirmajam dokumentų blokui, o visais kitais atvejais - jau antrajam.

Notarinių įrašų blokui priklausys visi turto ir valdų pirkimo ir pardavimo, arendos ir ikeitimo, dovanojimo, mainų, dalybų aktai, visi skolraščiai ir testamentai, kilnojamojo 
ir nekilnojamojo turto inventoriai ir sąrašai, taip pat susitaikymai, leidimo ir kvitavimo raštai ir dar daug kitokių smulkesnių ir retesnių notarinių ịrašų, pavyzdžiui, pranešimai apie kraičio ar vainiko sumokẻjimą ar kilusius gaisrus. O juridiniai-procesiniai aktai yra visi įrašai, kurie sudaryti arba teismo pareigūnų, arba bajorams kreipiantis ị žemės teismą jau ne kaip ị notarinę, o ị teismo įstaigą. Šie aktai dalijami $\mathfrak{i}$ tris dideles grupes. Visų pirma tai teismo nutartys ar jų nukèlimas, jų perdavimas kitiems teismams. Visų antra tai vaznių (teismo vykdytojų) pareiškimai apie teismo nuosprendžių îvykdymą ar neįvykdymą, ịvairių teismo šaukimų teikimą ar neįteikimą, vaznių dalyvavimas įvertinant skundèjų nuostolius ir žaizdas, bajorų šaukimai ị teismą. Trečioji grupe - tai bylos pusių atvykimo ar neatvykimo paliudijimas, ịgaliojimai atstovauti kitiems ar paimti pinigus ir pan.

Žinoma, labai griežtai atriboti visų įrašų neįmanoma, todèl abiejuose aktų blokuose neišvengiamai atsiranda kitų atskirų ịrašų grupelè, kur fiksuoti pavieniai įrašai. Taip pat reikia pabrèžti, kad dèl fragmentiško išlikusių šaltinių pobūdžio negalima kalbèti apie visą pavietų žemės teismų darbo panoramą. Siūloma žemès teismo knygų tyrimo schema taip pat nèra baigtinè, ateityje ji gali būti tobulinama ar išplèsta.

Istoriografija ir tyrimo objektas. LDK pavietų žemės teismo knygų turinys nèra daug tyrinètas. XX a. pradžioje keliasdešimt Žemaitijos žemės teismo knygų, saugomų Vilniaus centriniame senųjų aktų archyve, aprašè I. Sprogis ir jo pagalbininkai [86, d. I-V]. Neseniai bandyta aprašyti ir Žemaičių žemès teismų knygų turinị iki Trečiojo Statuto priemimo [79, 359-361]. Labai panašią tyrimo schemą naudoja ukrainiečių istorikè Natalija Starčenko, tyrinëjanti Voluinès pilies teismų darbą XVI a. pabaigoje [90-91] (1), panašų tyrimą Baltarusijoje atliko A. Radamanas [89]. Lietuvoje ankstyvuosius „žemès“ teismus tyrinèjo E. Gorodeckas [75]. Žemaičių bajorijos šeiminius ryšius XVI a. pabaigoje nagrinejjo R. Trimonienė [77]. Geografiškai ir chronologiškai N. Starčenkos tyrimui artimą temą kitu rakursu aptarẻ V. Poliščiukas [87-88]. Iš Lietuvos istorikų, tyrusių Žemaitijos realijas, būtina paminèti E. Saviščevą [76] ir J. Drungilą [74].

Po 1564-1566 m. teismo sistemos reformos Žemaitija turejjo vieną pavieto teismą visai seniūnijai, kuris iš pradžių neturèjo pastovios darbo vietos, o maždaug nuo XVI a. 8-ojo dešimtmečio pradejo dirbti Raseiniuose, kurie ir tapo administraciniu Žemaitijos centru. Žemaitija apèmé apie $21000 \mathrm{~km}^{2}$, o žinant, kad jos bajorija sudarẻ beveik dešimtadalị visų gyventojų, nereikia stebètis, kad dar to paties amžiaus pabaigoje Žemaičių teismų knygos išaugo iki didžiulių foliantų.

Tyrimui pasirinkta keliasdešimt ankstyvųjų (iki XVI a. pabaigos) rankraštinių Žemaitijos žemės teismo knygų, saugomų Lietuvos Respublikos bibliotekose ir archyvuose. Seniausios Žemaitijos žemès teismo knygos sudaro didžiulį archyvinị masyvą, kuriame yra keliasdešimt ịvairaus dydžio žemès teismo knygų.

Pirmosios Žemaitijos žemės teismo knygos ir jų turinys (iki 1600 m.) buvo aprašytas jau minètame Vilniuje leistame Vilniaus centrinio Senujų aktų knygu archyvo dokumentų apraše; penkiose pirmosiose jo dalyse buvo aprašyta 41 tada archyve buvusi žemès teismo knyga.

$\mathrm{XX}$ a. istoriniai kataklizmai nepasigailèjo carinio Vilniaus Senųjų aktų archyvo. Jame saugomos knygos nuo Pirmojo pasaulinio karo pradejo savo nesibaigiančias keliones, kurios tęsèsi maždaug pusšimtị metų. Iš pradžių didesnẻ pavietų teismų knygų dalis $1915 \mathrm{~m}$.

(1) Ši istorike pranešimą ta tema perskaitè XX Lenkijos MA Lituanistinès komisijos konferencijoje 20110928 - „O efektywności funkcjowania sądownictwa grodzkiego na Wołyniu w końcu XVI wieku (do pytania o kulturze prawnej szlachty wołyńskiej)“" (spaudoje, bus publikuotas $2013 \mathrm{~m}$. pabaigoje). 
buvo evakuota ị Rusijos gilumą. Po 1917 m. didesnè jų dalis (tačiau ne visos) sugrị̌zo ị nepriklausomą Lietuvą, Kauną bei Vilnių, tada buvusị Lenkijos valdžioje.

Po 1939 m. archyvinių knygų klajonès tęsèsi. Dalis jų buvo išvežta į Minską; Antrojo pasaulinio karo metais, padedant kun. J. Stakauskui, sugrị̌zo ị Vilnių. Iš ten jos 6-ajame to amžiaus dešimtmetyje vèl buvo išvežtos ị Baltarusiją, didesnè dalis - $\mathfrak{i}$ Minską, kita dalis - $\mathfrak{i}$ Gardiną, pagaliau 7-ajame to amžiaus dešimtmetyje visos suvežtos i Minską. Klajojo ir i Lietuvą prieškariu patekusios pavietų teismų knygos. Kaune jos pateko į Vytauto Didžiojo universiteto biblioteką, iš ten apie 1950 m., likviduojant VDU, buvo pervežtos į Vilniaus universitetą ir atsidūrẻ jo bibliotekos Rankraščių skyriaus fonde Nr. 7. Beveik visos darbe nagrinëjamos seniausios Žemaitijos žemès teismo knygos yra minètame VU bibliotekos rankraščių skyriaus fonde, dar dvi išliko LVIA fonduose.

$* * *$

Atrodo, kad nepamainomu pagalbininku šiame tyrime turètų būti didelès Žemaičių žemés teismo knygos, kurių nemažai išliko nuo 1575 metų. Juolab kad tyrimą turètų supaprastinti ir jau egzistuojantys seniausiųjų (iki XVI a. pabaigos) Žemaičių žemės teismo knygų aprašai. Deja, šis ịspūdis yra apgaulingas. Mat prieš daugiau nei šimtmetị Vilniaus archyvaro Ivano Sprogio parengti aprašai jau nèra tikslūs. Visų pirma ne visur sutampa tada aprašytų ir dabar išlikusių knygų apimtys. Visų antra, o tai svarbiausia, praeito amžiaus archyvarus gluminusios Žemaičių žemès teismo knygos tarpukariu buvo perrištos ir padalytos ị dvi knygų serijas - A seriją (žemės teismo knygos) ir B seriją (žemès teismo bylos). Taigi kai kurios iš I. Sprogio aprašytų knygų jau neegzistuoja, nes yra perrištos iš naujo - jos perskirtos, sujungtos ir pan. Tokios jos išliko Vilniaus universiteto Rankraščių skyriaus fonde Nr. 7 (2). Beje, iš šio aprašo aiškejja, kad XVII a. pradžioje buvo daugiau bylų nei aktų knygų.

Kodèl taip atsitiko? I ši klausimą padeda atsakyti išlikusių Žemaitijos knygų peržiūra. Pirmose Žemaitijos žemès teismo knygose yra beveik vien notariniai įrašai. Tik vèlesnèse, jau XVI a. 9-ojo dešimtmečio, knygose atsiranda ir juridinių-procesinių įrašų. Todèl XX a. 4-ojo dešimtmečio archyvarai ir „sutvarke்“ tas knygas - ne tik perrišo jas padieniui, lyg nebūtų supratę, kad teismo sesiją gali sudaryti keletas vèlesnių sąsiuvinių, kuriuos vedè atskiri paraštininkiai (3), bet ir išskaidè teismo knygas pagal ịrašų rūši (4), tokiu būdu sukurdami žemés teismo aktu (A) ir žemés teismo bylu (B) serijas. Kai kur, pavyzdžiui, buvusioje $1582 \mathrm{~m}$. Žemaitijos žemès teismo knygoje Nr. 14579, tai pavyko lengvai padaryti perskiriant notarinę knygos dalị nuo juridinès-procesinės jos pabaigos: 118 pirmų ịrašų tapo Žemaitijos žemès teismo aktų knyga Nr. 3 (VUBRS, f. 7, Nr. 300), o tolesni 54 teismo sprendimai pradeda Žemaitijos žemès bylų seriją (VUBRS, f. 7, Nr. 362). Dabartinèje šio teismo knygų klasifikacijoje tai yra Žemaitijos trečioji ir ketvirtoji žemès teismo knygos [3-4]. Tačiau vèlesnėms žemės teismo knygoms pasisekè mažiau - notariniai ir juridiniaiprocesiniai ịrašai jose sumaišyti, todẻl tokių "grynų“ vieno ar kito tipo knygų suformuoti nepavyko. Tokia revizija niekais paverte ir XX a. pradžios Vilniaus archyvarų pastangas aprašyti knygas - tada VCA knygų aprašo serijoje suregistruotas Žemaitijos žemès teismo

(2) VUBRS, f. 7, A serija - Nr. 297-351 ir B serija - Nr. 362-494, toliau vèl eina aktų knygos. Tų serijų išskyrimas yra atskiro stambaus tyrimo objektas.

(3) Taip buvo „sutvarkyta“ pirmoji Žemaitijos žemès teismo knyga, apie tai žr. [82, 246-247, nuor. 34]. Beje, taip padieniui „sutvarkytos“ ir kai kurios kitos žemès teismo knygos, pvz., Upytės žemès teismo knyga Nr. 3 (1584-1586) [83].

(4) Apie tai yra rašiusi E. Eitmaityte [72, 27-30]. 
1 lentelè. I. Sprogio aprašytos Žemaitijos žemės teismo knygos (Описи документов Виленского Центрального архива древних актовых книг (toliau - Описи ВЦА), вып. I-V, Вильна, 1901-1907)

\begin{tabular}{|c|c|c|c|c|c|}
\hline Eil. Nr. & Knyga & Metai & Lapu sk. & Irašų sk. & Palyginti su VUBRS, f. 7 \\
\hline $1 / 14575$ & Žemaitijos I & 1575 & 850 & 403 & Sutampa su f. 7, Nr. 298 \\
\hline $2 / 14576$ & Žemaitijos II & 1578 & 663 & 343 & Beveik sutampa su f. 7, Nr. 299 \\
\hline $3 / 14577$ & Žemaitijos III & 1578-1579 & 451 & 286 & Dingusi \\
\hline $4 / 14578$ & Žemaitijos IV & 1581 & 464 & 263 & Dingusi \\
\hline $5 / 14579$ & Žemaitijos V & 1582 & 324 & 172 & $\begin{array}{c}\text { Padalyta i dvi knygas, f. } 7 \\
\text { Nr. } 300 \text { ir } 362\end{array}$ \\
\hline $6 / 14580$ & Žemaitijos VI & 1583 & 390 & 302 & \\
\hline $7 / 14581$ & Žemaitijos VII & 1584 & 501 & 390 & $\begin{array}{l}\text { Padalyta i f. } 7 \text { Nr. } 301 \text { ir be } \\
\text { Nr. (dalis Žemaičių VII ŽTK) }\end{array}$ \\
\hline $8 / 14582$ & Žemaitijos VIII & $1584-1599$ & 808 & 463 & Padalyta pamečiui \\
\hline $9 / 14583$ & Žemaitijos IX & 1585 & 541 & 336 & Padalyta \\
\hline $10 / 14584$ & Žemaitijos X & 1585 & 199 & 124 & Padalyta? \\
\hline $11 / 14585$ & Žemaitijos 11-oji & 1586 & 378 & 227 & $\begin{array}{c}\text { Sutampa su LVIA, SA, Gorb. } \\
\text { Nr. } 14585 \\
\end{array}$ \\
\hline $12 / 14586$ & Žemaitijos 12-oji & 1586 & 361 & 257 & $\begin{array}{c}\text { Sutampa su LVIA, SA, Gorb. } \\
\text { Nr. } 14586\end{array}$ \\
\hline $13 / 14587$ & Žemaitijos 13-oji & 1588 & 280 & 205 & \\
\hline $14 / 14588$ & Žemaitijos 14-oji & 1588 & 350 & 279 & \\
\hline $15 / 14589$ & Žemaitijos 15 -oji & $1588-1590$ & 500 & 519 & $\begin{array}{c}\text { Padalyta pamečiui. Dalis } \\
\text { priklauso ŽŽB-3 }\end{array}$ \\
\hline $16 / 14590$ & Žemaitijos 16-oji & 1590 & 179 & 234 & \\
\hline $17 / 14591$ & Žemaitijos 17-oji & 1590 & 1010 & 795 & \\
\hline $18 / 14592$ & Žemaitijos 18-oji & 1591 & 714 & 402 & Sutampa su f. 7, Nr. 308 \\
\hline $19 / 14593$ & Žemaitijos 19-oji & 1592 & 387 & 228 & Sutampa su f. 7, Nr. 309 \\
\hline $20 / 14594$ & Žemaitijos 20-oji & 1592 & 449 & 247 & Sutampa su f. 7, Nr. $310 ?$ \\
\hline $21 / 14595$ & Žemaitijos 21-oji & 1592 & 430 & 251 & \\
\hline $22 / 14596$ & Žemaitijos 22-oji & 1593 & 382 & 214 & Sutampa su f. 7, Nr. 311 \\
\hline $23 / 14597$ & Žemaitijos 23-oji & 1593 & 643 & 353 & Sutampa su f. 7, Nr. 312? \\
\hline $24 / 14598$ & Žemaitijos 24-oji & 1594 & 245 & 140 & \\
\hline $25 / 14599$ & Žemaitijos 25 -oji & 1595 & 828 & 403 & \\
\hline $26 / 14600$ & Žemaitijos 26-oji & 1595 & 611 & 334 & Sutampa su f. 7, Nr. 313 \\
\hline $27 / 14601$ & Žemaitijos 27-oji & 1595 & 862 & 420 & Sutampa su f. 7, Nr. 314 \\
\hline $28 / 14603$ & Žemaitijos 29-oji & 1596 & 744 & 381 & Sutampa su f. 7, Nr. 316 \\
\hline $29 / 14604$ & Žemaitijos 30-oji & 1596 & 394 & 208 & Neaišku, gal f. 7, Nr. 380? \\
\hline $30 / 14605$ & Žemaitijos 31-oji & 1596 & 460 & 268 & Sutampa su f. 7, Nr. 317 \\
\hline $31 / 14606$ & Žemaitijos 32-oji & 1597 & 448 & 232 & Sutampa su f. 7, Nr. 318 \\
\hline $32 / 14607$ & Žemaitijos 33-oji & 1597 & 602 & 278 & Sutampa su f. 7, Nr. 319 \\
\hline $33 / 14608$ & Žemaitijos 34-oji & 1597 & 467 & 224 & Sutampa su f. 7, Nr. $320 ?$ \\
\hline $34 / 14609$ & Žemaitijos 35-oji & 1598 & 284 & 148 & Sutampa su f. 7, Nr. 321 \\
\hline $35 / 14610$ & Žemaitijos 36-oji & 1598 & 443 & 213 & \\
\hline $36 / 14611$ & Žemaitijos 37-oji & 1598 & 1025 & 517 & Padalyta? \\
\hline $37 / 14612$ & Žemaitijos 38-oji & 1599 & 831 & 401 & Gal f. 7, Nr. 389-393? \\
\hline $38 / 14613$ & Žemaitijos 39-oji & 1599 & 1039 & 517 & Sutampa su f. 7, Nr. $324 ?$ \\
\hline $39 / 14614$ & Žemaitijos 40-oji & 1599 & 167 & 83 & Sutampa su f. 7, Nr. 325 \\
\hline $40 / 14615$ & Žemaitijos 41-oji & 1600 & 440 & 219 & Sutampa su f. 7, Nr. $326 ?$ \\
\hline $41 / 14616$ & Žemaitijos 42-oji & 1600 & 734 & 350 & Sutampa su f. 7, Nr. 328 \\
\hline
\end{tabular}


2 Ientelè. I. Sprogio aprašytų Žemaitijos žemės teismo knygų (1575-1600) ̨rašų turinys

\begin{tabular}{|c|c|c|c|c|c|}
\hline Eil. Nr. & Knyga ir metai & $\begin{array}{l}\text { Iš viso } \\
\text { irašu }\end{array}$ & $\begin{array}{l}\text { Išju } \\
\text { notar. }\end{array}$ & $\begin{array}{l}\text { Iš jụ jurid-proc. } \\
\text { [iš jų nuospr.] }\end{array}$ & Pastabos \\
\hline $1 / 14575$ & Žemaitijos, 1575 & 403 & 399 & $4[0]$ & \\
\hline $2 / 14576$ & Žemaitijos II, 1578 & 343 & 324 & $19[7]$ & \\
\hline $3 / 14577$ & Žemaitijos III, 1578-1579 & 286 & 190 & $96[16]$ & Dingusi \\
\hline $4 / 14578$ & Žemaitijos IV, 1581 & 263 & 225 & 38 [3] & Dingusi* \\
\hline $5 / 14579$ & Žemaitijos V, 1582 & 172 & 118 & 54 [19] & $\begin{array}{c}\text { Dabar padalyta į aktų } \\
\text { ir bylu knygas }\end{array}$ \\
\hline $6 / 14580$ & Žemaitijos VI, 1583 & 302 & 133 & $169[32]$ & Padalyta \\
\hline $7 / 14581$ & Žemaitijos VII, 1584 & 390 & 213 & $177[14]$ & Sumaišytos įrašų rūšys \\
\hline $8 / 14582$ & $\begin{array}{l}\text { Žemaitijos VIII, } \\
\text { 1584-1599 }\end{array}$ & 463 & 421 & $\begin{array}{c}38: 23-15[0] \\
\text { 12:12[0]; } \\
66: 40-26[10] \\
347: 336-11[2]\end{array}$ & $\begin{array}{c}1584 \text { m. - } 38 \text { dok.; } \\
1589 \text { m. - } 12 \text { dok.; } \\
1590 \text { m. [91, 93] - } 66 \text { dok.; } \\
1599 \text { m. - } 347 \text { dok.; padalyta } \\
\text { chronologiškai ir tematiškai }\end{array}$ \\
\hline $9 / 14583$ & Žemaitijos IX, 1585 & 336 & 218 & 118 [33] & Nuosprendžiai knygos gale \\
\hline $10 / 14584$ & Žemaitijos X, 1585 & 124 & 56 & $68[30]$ & Nuosprendžiai knygos gale \\
\hline $11 / 14585$ & Žemaitijos 11-oji, 1586 & 227 & 99 & $128[42]$ & $\begin{array}{l}\text { Dabar LVIA. Nuospren. } \\
\text { daugiausia knygos gale }\end{array}$ \\
\hline $12 / 14586$ & Žemaitijos 12-oji, 1586 & 257 & 105 & $152[40]$ & $\begin{array}{c}\text { Dabar LVIA. Nuospren. } \\
\text { knygos gale }\end{array}$ \\
\hline $13 / 14587$ & Žemaitijos 13-oji, 1586 & 205 & 106 & 99 [29] & $\begin{array}{l}\text { Nuospren. daugiausia } \\
\text { knygos gale }\end{array}$ \\
\hline $14 / 14588$ & Žemaitijos 14-oji, 1588 & 279 & 164 & $115[23]$ & Nuospren. knygos gale \\
\hline $15 / 14589$ & $\begin{array}{c}\text { Žemaitijos 15-oji, } \\
1589-1590\end{array}$ & 519 & 113 & $406[80]$ & $\begin{array}{l}\text { Padalyta. Nuosprend. } \\
\text { daugiausia knygos gale }\end{array}$ \\
\hline $16 / 14590$ & Žemaitijos 16-oji, 1590 & 234 & 75 & 159 & $\begin{array}{l}\text { Padalyta? 2-oje dalyje tik } \\
\text { skundai ir vaznių praneš. }\end{array}$ \\
\hline $17 / 14591$ & Žemaitijos 17-oji, 1590 & 795 & 553 & 242 & $\begin{array}{l}\text { 2-oje dalyje daugiausia } \\
\text { vaznių skundai }\end{array}$ \\
\hline $18 / 14592$ & Žemaitijos 18-oji, 1591 & 402 & 396 & 6 & \\
\hline $19 / 14593$ & Žemaitijos 19-oji, 1592 & 228 & 228 & 0 & \\
\hline $20 / 14594$ & Žemaitijos 20-oji, 1592 & 247 & 247 & 0 & \\
\hline $21 / 14595$ & Žemaitijos 21-oji, 1592 & 251 & 251 & 0 & \\
\hline $22 / 14596$ & Žemaitijos 22-oji, 1593 & 214 & 214 & 0 & \\
\hline $23 / 14597$ & Žemaitijos 23-oji, 1593 & 353 & 352 & 1 & \\
\hline $24 / 14598$ & Žemaitijos 24-oji, 1594 & 140 & 135 & 5 & \\
\hline $25 / 14599$ & Žemaitijos 25-oji, 1595 & 403 & 401 & 2 & \\
\hline $26 / 14600$ & Žemaitijos 26-oji, 1595 & 334 & 332 & 2 & \\
\hline $27 / 14601$ & Žemaitijos 27-oji, 1595 & 420 & 420 & 0 & \\
\hline $28 / 14603$ & Žemaitijos 29-oji, 1596 & 381 & 379 & 2 & \\
\hline $29 / 14604$ & Žemaitijos 30-oji, 1596 & 208 & 206 & 2 & \\
\hline $30 / 14605$ & Žemaitijos 31-oji, 1596 & 268 & 263 & 5 & $\begin{array}{c}\text { 2-oje dalyje daugiausia seni } \\
\text { peraktavimai }\end{array}$ \\
\hline $31 / 14606$ & Žemaitijos 32-oji, 1597 & 232 & 232 & 0 & \\
\hline
\end{tabular}

* İdomumo dèlei peržiūrètas ir dingusių knygų aprašas VCA I tome. 
2 lentelè. Tęsinys

\begin{tabular}{|c|c|c|c|c|c|}
\hline Eil. Nr. & Knyga ir metai & $\begin{array}{c}\text { Ǐ̌ viso } \\
\text { irašu }\end{array}$ & $\begin{array}{c}\text { Iš jų } \\
\text { notar. }\end{array}$ & $\begin{array}{c}\text { Ǐš jụ jurid-proc. } \\
\text { [iš jų nuospr.] }\end{array}$ & Pastabos \\
\hline $32 / 14607$ & Žemaitijos 33-oji, 1597 & 278 & 273 & 5 & \\
\hline $33 / 14608$ & Žemaitijos 34-oji, 1597 & 224 & 220 & 4 & \\
\hline $34 / 14609$ & Žemaitijos 35-oji, 1598 & 148 & 148 & 0 & \\
\hline $35 / 14610$ & Žemaitijos 36-oji, 1598 & 213 & 213 & 0 & \\
\hline $36 / 14611$ & Žemaitijos 37-oji, 1598 & 517 & 510 & 7 & \\
\hline $37 / 14612$ & Žemaitijos 38-oji, 1599 & 401 & 398 & 3 & \\
\hline $38 / 14613$ & Žemaitijos 39-oji, 1599 & 517 & 517 & 0 & \\
\hline $39 / 14614$ & Žemaitijos 40-oji, 1600 & 83 & 83 & 0 & \\
\hline $40 / 14615$ & $\begin{array}{c}\text { Žemaitijos 41-oji, } \\
1600\end{array}$ & 219 & 216 & 3 & \\
\hline $41 / 14616$ & $\begin{array}{c}\text { Žemaitijos 42-oji, } \\
1600\end{array}$ & 350 & 344 & 6 & \\
\hline
\end{tabular}

knygas dabar atsekti gana keblu. Laimé, kad B serijoje iki 1588 m. tokių teismo bylų knygu yra tik dvi (5); tiesa, nuo $1590 \mathrm{~m}$. jos eina lygiagrečiai su $A$ serijos knygomis beveik pamečiui. Palyginimui galima peržvelgti Ivano Sprogio sudarytų Žemaitijos knygų aprašą ir dabartinių Žemaitijos knygų būklę (iki 1600 m.). Nesutampa net to laikotarpio buvusių ir dabar esamų knygų skaičius.

Kaip matome, XX a. pradžioje I. Sprogiui ir jo padejejams nekilo jokių problemų aprašinėjant Žemaičių žemės teismo knygas, nes tada visos jos priklausẻ žemės teismo aktams [85, 518-519]. Netgi galima tvirtinti, kad dauguma jo aprašytų knygų buvo, naujoviškai kalbant, „aktų“, arba A serijos, knygos. Dabar Žemaičių žemès teismo knygos gana smarkiai sumaišytos ir netgi pagrindinei lygiagrečios serijos (vadinamosios $B$ serijos) sukūrimas nesuteikia visiško aiškumo. Labai sunku suprasti, kaip 39 (dvi knygos dingusios) tuometinès Žemaitijos žemès teismo knygos buvo išskaidytos ị daugiau nei septyniasdešimt dabartinių, juolab kad net ne visos dabartinès $V U B$ rankraštyne esančios Žemaičių žemès teismo knygos neturi eilès numerio. Žemaičių žemès teismų knygų fragmentų skaidymas ir vertimas atskirais saugojimo vienetais (knygomis) vyksta ir šiomis dienomis jas restauruojant (2013 m. vidurio žinios).

Didžiausia problema yra ta, kad iš pateiktų duomenų matome, jog didesnę tuometinių I. Sprogio aprašytų žemès teismo knygų dali pakartoja ir "padengia“ dabartinè teismo knygų $A$ serija (teismo aktai). O naujoji, $B$ serija (teismo bylos), tiesiog neịtikètinai viršija visus nurodytus XX a. pradžios teismo knygų dydžius. Nemažą medžiagos „pervirš̌i“ galima paaiškinti tik taip: teismo bylų knygos yra mažesnès, nei nurodyta f. 7 apraše. Tą patị, beje, galima pasakyti ir apie kai kurias žemès teismo aktų bylas. Atmetus sutrūnijusių knygų dalis, galima daugiau ar mažiau tiksliai atkurti visą knygų masyvo dydị. Iš viso I. Sprogis aprašè 41 knygą su 22210 lapų (915 lapų dingusiose knygose), taigi lieka 21295 lapai. Dabar VUB rankraštyne yra per septyniasdešimt (73) dviejų serijų knygų (16 213 ir 9644 lapai) ir 2 knygos yra LVIA (739 lapai). Taigi gauname 26595 lapus - daug daugiau nei I. Sprogio aprašytų daugiau nei 5000 lapų. Vargu ar tokia paklaida yra natūrali. Taigi galime teigti, kad daugelio $B$ serijos knygų I. Sprogis neaprašè, nes nematè, tą patvirtina 3-ioji lentelè.

(5) Mašinraštinis VU bibliotekos Rankraščių skyriaus fondo Nr. 7 aprašas. 
3 lentelè. Žemaitijos žemès teismo knygų $B$ serija (teismo „,sprendimai“)

\begin{tabular}{|c|c|c|c|c|}
\hline $\begin{array}{l}\text { Eilès Nr. } \\
\text { VUB, } \\
\text { f. } 7\end{array}$ & $\begin{array}{l}\text { Knygos eiles Nr. B serijoje } \\
\text { ir jos metai }\end{array}$ & $\begin{array}{l}\text { Lapu skaičius } \\
\text { VUB apraše } \\
\text { (real.) }\end{array}$ & llrašų sk. & Pastabos \\
\hline $362 / 1$ & $\begin{array}{l}\text { Žemaičiu žemės bylos } \\
\text { Nr. } 1 \text { (toliau ŽŽB-n), } \\
\text { Ž 134,1 [14 579], } 1582\end{array}$ & 83 lapai & 54 & $\begin{array}{c}\text { Tai Gorbač. kn. Nr. } 14579 \text { galas } \\
\text { (paskutiniai } 54 \text { dok.) - VCA, t. } 1 \text {, } \\
\text { p. } 84-87\end{array}$ \\
\hline $363 / 2$ & ŽŽB-2, Ž 134,2, 1584 & 86 & 30 & $\begin{array}{c}\text { Knyga jau aprašyta } \\
{[78,190-191]}\end{array}$ \\
\hline $364 / 3$ & ŽŽB-3, Ž 134,3, 1590 & 335 (336 p.) & $462 \mathrm{~d}$. & $\begin{array}{c}\text { Iš tikro } 336 \text { p., dalis aprašyta } \\
V C A, \text { t. } 2\end{array}$ \\
\hline $365 / 4$ & ŽŽB-4, Ž 134,4, 1591 & $268(272)$ & $184 \mathrm{~d}$. & Iš tikro $272 \mathrm{I}$. \\
\hline $366 / 5$ & ŽŽB-5, Ž 135, 1591-1592 & $307(293)$ & $473 \mathrm{~d}$. & Iš tikro 293 I. \\
\hline $367 / 6$ & ŽŽB-6, Ž 136, 1592 & 259 & $495 \mathrm{~d}$. & \\
\hline $368 / 7$ & ŽŽB-7, 1592 & 252 & $486 \mathrm{~d}$. & \\
\hline $369 / 8$ & ŽŽB-8, 1592 & $\sim 740$ (748) & $518 \mathrm{~d}$. & Iš tikro $748 \mathrm{I}$. \\
\hline $370 / 9$ & ŽŽB-9, 1593 & 421 & $?$ & Restauruojama nuo 2006 m. \\
\hline $371 / 10$ & ŽŽB-10, Z 1311, 1593 & 292 & $168 \mathrm{~d}$. & \\
\hline $372 / 11$ & ŽŽB-11, Z 1311, 1593 & 314 & $653 \mathrm{~d}$. & \\
\hline $373 / 12$ & ŽŽB-12, 1593 & $\sim 605(600)$ & $371 \mathrm{~d}$. & Iš tikro $600 \mathrm{I}$. \\
\hline $374 / 13$ & ŽŽB-13, 1594 & $197(260)$ & $177 \mathrm{~d}$. & Iš tikro $260 \mathrm{l}$. \\
\hline $375 / 14$ & ŽŽB-14, 1594 & $\sim 260$ (198) & $382 \mathrm{~d}$. & Iš tikro $198 \mathrm{I}$. \\
\hline $376 / 15$ & ŽŽB-15, Z 1316, 1595 & $322(332)$ & $186 \mathrm{~d}$. & Iš tikro $332 \mathrm{I}$. \\
\hline $377 / 16$ & ŽŽB-16, Z 1316, 1595 & $315(180)$ & $331 \mathrm{~d}$. & Iš tikro $180 \mathrm{I}$. \\
\hline $378 / 17$ & ŽŽB-17, ŽB 18, 1595 & $458(455)$ & $273 \mathrm{~d}$ & Iš tikro 455 I., yra internete \\
\hline $379 / 18$ & ŽŽB-17a, 1595 & $450(440)$ & $953 \mathrm{~d}$. & Iš tikro $440 \mathrm{I}$. \\
\hline $380 / 19$ & ŽŽB-18, M 15, 1596 & $420(421)$ & $230 \mathrm{~d}$ & Iš tikro $421 \mathrm{I}$. \\
\hline $381 / 20$ & ŽŽB-19, ŽB 19, $1595 ?$ & $327(346)$ & $680 \mathrm{~d}$. & Iš tikro 346 I. \\
\hline $382 / 21$ & ŽŽB-19, M 21, 1597 & $\sim 110(124)$ & $383 \mathrm{~d}$. & Iš tikro 124 I., jau nuskaitmen. \\
\hline $383 / 22$ & ŽŽB-20, ŽB 24, 1597 & $327(30)$ & 69 dok. & $\begin{array}{c}\text { Einam. reikalu, nunykusi, restaur. } \\
\text { išlikę tik } 30 \text { I., yra internete }\end{array}$ \\
\hline $384 / 23$ & ŽŽB-21, ŽB 25, 1597 & $\sim 130$ (136) & 343 dok. & Iš tikro $136 \mathrm{I}$. \\
\hline $385 / 24$ & ŽŽB-22, ŽB 26, 1597 & 300 & $?$ & Skaitmeninama \\
\hline $386 / 25$ & ŽŽB-23, ŽB 27, 1597 & $200(203)$ & $\begin{array}{c}\sim 500, \text { numer. } \\
\text { tik } \sim 400 \mathrm{~d} .\end{array}$ & $\begin{array}{c}\text { Supuvusi, restaur., yra internete. } \\
\text { Paskut. } 50 \text { lapų nunykę }\end{array}$ \\
\hline $387 / 26$ & ŽŽB-24, M 28, 1597 & $415(424)$ & $240 \mathrm{~d}$ & Iš tikro 424 I. \\
\hline $388 / 27$ & ŽŽB-25, B 29, 1598 & $290(288)$ & $665 \mathrm{~d}$. & Iš tikro $288 \mathrm{I}$. \\
\hline 389 & ŽŽB-26, ŽB 30 & $?$ & $?$ & $V U B, f .7$ fonduose nèra \\
\hline $390 / 28$ & ŽŽB-[29], ŽB 34, 1599 & 229 & $634 \mathrm{~d}$. & \\
\hline $391 / 29$ & ŽŽB-27, ŽB 32, 1599 & $387(391)$ & $179 \mathrm{~d}$. & Iš tikro $391 \mathrm{I}$. \\
\hline $392 / 30$ & ŽŽB-28, ŽB 35, 1599 & $\sim 185(187)$ & $405 \mathrm{~d}$. & Iš tikro $187 \mathrm{I}$. \\
\hline $393 / 31$ & ŽŽB-29, ŽB 35, 1599 & $\sim 300(304)$ & $165 \mathrm{~d}$. & Iš tikro $304 \mathrm{I}$. \\
\hline $394 / 32$ & ŽŽB-30, ŽB 36, 1599 & 258 & $?$ & Skaitmeninama \\
\hline $395 / 33$ & ŽŽB-31, M 37a, 1600 & $\sim 162(162)$ & $390 \mathrm{~d}$. & Iš tikro $162 \mathrm{I}$. \\
\hline $396 / 34$ & ŽŽB-32, Ž 1337b, 1600 & 79 & $?$ & Skaitmeninama \\
\hline $397 / 35$ & ŽŽB [33,38], 1600 & $299+2$ & $?$ & Skaitmeninama \\
\hline $398 / 36$ & ŽŽB-34, Ž 1339, 1600 & $140+4(144)$ & $100 \mathrm{~d}$. & Iš tikro $144 \mathrm{I}$. \\
\hline
\end{tabular}


Iš 3-ios lentelès medžiagos matome, kad ši $B$ serija nebuvo vienalytė. Ją galima padalyti ì du pogrupius, arba rūšis. Dalị tokių knygų sudarè vadinamosios „einamųjų reikalų“ (lenkiškai - potocznyje sprawy) knygos, kuriose tik fiksuoti bajorų skundai, vaznių pranešimai ir kitos ikiprocesinès teismo darbo aplinkybès. Tokiose knygose dažnai viename lape būna įrašyta po 3-4 dokumentus, o žemès teismo knygos, kuriose įrašyti sprendimai, pasižymi ilgais procesų aprašymais. Žinoma, tarp šių knygų pasitaiko ir tokių, kuriose einamieji reikalai ir teismo sprendimai įrašyti kartu, kartais ir sumaišyti tarpusavyje.

Labiausiai pasiseke Žemaitijos XI ir XII žemės teismo aktų knygoms, kažkodèl likusioms Lietuvos valstybės istorijos archyve ir todèl nedalytoms ir „nerūšiuotoms“ [1112] (6). Kaip matome, didesnè dalis šio laikotarpio Žemaitijos žemès teismo knygu yra performuotos - išskaidytos ir perrištos, todèl pasinaudoti I. Sprogio atliktu XVI a. pabaigos Žemaitijos žemès teismo knygų aprašymu yra gana sudètinga.

Kaip ten bebūtų ir kaip beaiškintume bylų serijos ( $B$ serija) atsiradimą, aišku, kad 36 šios serijos knygos, turinčios nuo 79 (f. 7, Nr. 396) iki 740 (f. 7, Nr. 369) lapų, smarkiai viršija visų galimų I. Sprogio aprašytų knygų dydị, nors ir tenka konstatuoti, kad pirmosios dvi (Nr. 362 ir 363) anksčiau atskirai aptartos bylų serijos knygos tikrai sudarytos iš senụjų aktų knygų, mechaniškai atskyrus nuo jų juridines-procesines tų knygų dalis. Tas pats atsitiko ir su trečiąja $B$ serijos knyga, kuri sudaryta išskiriant aprašytąją.

Taigi galima teigti, kad tiksliai nustatyti visų esamų Žemaitijos knygų skaičiaus nèra immanoma. Apgailestaujant tenka konstatuoti, kad išlikusi Žemaitijos žemès teismo medžiaga ne tik pasižymi ypatinga gausa, jai reikia ir naujo, kokybiškai kitokio nei naudotas jų tyrimo būdo, nes teismų knygos čia jau išskirtos ị aktų ir bylų serijas.

Iš nurodytos medžiagos aiškẻja, kad XVI a. pabaigoje Žemaitijos žemès teismo knygose palengva daugèjo nenotarinių ịrašų. Nors iš pradžių teisminio pobūdžio ịrašų pasitaiko ir I. Sprogio aprašytose teismo knygose, kurios XX a. priskirtos Aktų (A serija) knygų serijai, maždaug nuo paskutiniojo XVI a. dešimtmečio Žemaitijoje gana griežtai išsiskiria aktų ir teismo bylų knygų serijos, pastaroji dar išskiriama ị einamųjų reikalų ir procesų pogrupị. Jau nuo XVI a. paskutiniojo dešimtmečio pradžios Žemaitijoje žemès teismo darbo apimtis išsiplečia taip smarkiai, kad jo knygos dalijamos pagal teismo darbo pobūdị - i vienas ịrašomi daugiausia notariniai įrašai, ị kitas - tik skundai ar teismo vykdytojų (vaznių) pranešimai, dar ị kitas - jau paties teismo procesų aprašymai. XVI a. pabaigoje Raseiniuose rezidavęs žemès teismas buvo rimta ịstaiga, skleidusi ne tik teisminę kultūrą ar dirbusi kaip notarinė isstaiga, bet ir ženkliai prisidejjusi prie rašto kultūros plètros visoje Žemaičių seniūnijoje. Teismo sesijos tęsèsi iki dviejų mènesių, o per juos ị teismo knygas kasdien įrašoma nuo kelių iki keliolikos ịvairių ịrašų, ir tai liudija smarkiai išplètotą jo raštinès aparatą. Žemès teismo darbas specializuotas, žemės raštininko vadovaujami rašovai rašè skirtingas aktų, einamųjų reikalų ir teismo procesų knygas.

\section{IŠVADOS}

Išlikusios seniausios Žemaitijos žemės teismo knygos sudaro didžiulị archyvinị masyvą, kuriame yra per 70 ịvairaus dydžio žemès teismo knygų. Dalis pirmųjų Žemaitijos žemès teismo knygų ir jų turinys (iki $1600 \mathrm{~m}$.) buvo aprašyta XX a. pradžioje Vilniuje leistame Vilniaus centrinio Senujų aktų knygu archyvo dokumentų apraše, kur penkiose pirmosiose jo dalyse buvo aprašyta 41 tada archyve buvusi žemés teismo knyga.

(6) Žr. LVIA, Nr. 14585 ir Nr. 14586. 
I Lietuvą, Vytauto Didžiojo universiteto biblioteką Kaune, dar prieškariu patekusios pavietų teismų knygos (tarp jų ir Žemaitijos) apie 1950 m., likviduojant VDU, buvo pervežtos ị Vilniaus universitetą ir atsidūrè jo bibliotekos Rankraščiu skyriaus fonde Nr. 7. Darbe nagrinėjamos seniausios Žemaitijos žemės teismo knygos beveik visos yra minètame VU bibliotekos rankraščių skyriaus fonde, pora jų išliko LVIA fonduose.

Žemaitijos žemės teismo knygų tyrimą apsunkina tai, kad, palyginti su XX a. pradžioje Vilniaus senųjų aktų (VCA) archyve buvusiomis knygomis, jų skaičius ir dydis yra pakitę. Taip atsitiko todèl, kad tarpukariu didelè dalis Žemaitijos žemès teismo knygų buvo "modernizuotos“ - išsklaidytos ị aktų ir bylų dalis, kurios dabar vadinamos $A$ ir $B$ serijomis. Ir nors tai darę archyvarai buvo kupini geriausių intencijų, tačiau po tokios knygų skaičiaus ir tematinès reorganizacijos, jose susivokti pagal I. Sprogio darytus knygų aprašymus dažnai yra labai keblu, o kartais ir neįmanoma. Kai kurios dabartiniame VUB rankraštyno f. 7 esančios knygos iš viso neturi senųjų VCA eilès numerių...

Darbe siekiama aprašyti buvusias ir esamas Žemaitijos žemės teismo knygas dèl dviejų priežasčių. Visų pirma norèta palengvinti tyrèjų pastangas susiorientuoti dabartinèse teismo knygose, nes, skirtingai nuo, pvz., Baltarusijos, pavietų teismo knygų turinio vidiniai aprašai Lietuvoje po I. Sprogio išleistos serijos (jau daugiau nei 100 metų) nebuvo sudaromi. Taip pat siekta išsiaiškinti, kiek senụjų knygų perskyrimas ị aktų ir bylų knygas atitinka esamą realybę ir gali padèti (o gal net ir trukdo) suvokti Žemaitijos žemès teismo kasdienybę.

Notarinių ịrašų dalies daugèjimas pavietų žemės teismo knygose mums leidžia spèti, kad norint sèkmingai bylinètis teismuose, reikejjo ir dokumentų, įrodančių besibylinëjančių asmenų argumentų teisumą. Taigi notariniai ịrašai ne tik padejjo apsidrausti nuo dokumentų netekties, bet ir buvo vertinga medžiaga sprendžiant galimas teismines kolizijas (ginčai dèl turto, valdų, palikimo ir pan.). Kartu teisminių skundų ar nuostolių iૃrašymas į žemès teismo knygas rodo ir norą turèti teisminius svertus besibylinejjant su procesiniais oponentais. Tai rodo svarbų bajoriškosios savimonès - teisinès kultūros - formavimąsi ir stiprejjimą. Gausios ir sumaišytos Žemaitijos žemès teismų knygų medžiagos ịtraukimas ị bendrą LDK pavietų žemès teismų tyrimų kontekstą mums padès tirti bajorijos vaidmenị tų teismų darbe ir leis giliau išnagrinèti to luomo juridinès kultūros apraiškas.

Jau nuo XVI a. paskutiniojo dešimtmečio Raseiniuose rezidavęs Žemaičių žemès teismas buvo rimta įstaiga, skleidusi ne tik teisminę kultūrą ar dirbusi kaip notarine ịstaiga, bet ir ženkliai prisidejjusi prie rašto kultūros plètros visoje Žemaičių seniūnijoje. Jame vedamos trejopos - aktų, einamųų reikalų ir teismo procesų - knygos.

Gauta 20130603 Priimta 20131112

\section{Šaltiniai ir literatūra}

[1] Žemaitijos žemès teismo aktų (1575) knyga. VUBRS, f. 7, Nr. 298.

[2] Žemaitijos žemès teismo aktų (1578) knyga. VUBRS, f. 7, Nr. 299.

[3] Žemaitijos žemès teismo aktų (1582) knyga. VUBRS, f. 7, Nr. 300.

[4] Žemaitijos žemès teismo bylų (1582) knyga.VUBRS, f. 7, Nr. 362 (ŽŽB, Nr. 1).

[5] Žemaitijos žemès teismo aktų (1584) knyga. VUBRS, f. 7, Nr. 301.

[6] Žemaitijos žemès teismo bylų (1584) knyga. VUBRS, f. 7, be Nr., fakt. Nr. 301 tęsinys.

[7] Žemaitijos žemès teismo aktų (1584) knyga. VUBRS, f. 7, be Nr.

[8] Žemaitijos žemès teismo bylų (1584) knyga. VUBRS, f. 7, Nr. 363 (ŽŽB, Nr. 2). 
[9] Žemaitijos žemès teismo aktų (1585) knyga. VUBRS, f. 7, Nr. 297.

[10] Žemaitijos žemès teismo aktų (1585) knyga. VUBRS, f. 7, Nr. 302.

[11] Žemaitijos žemès teismo aktų (1586) knyga. LVIA, Gorb. katal. Nr. 14585.

[12] Žemaitijos žemès teismo aktų (1586) knyga. LVIA, Gorb. katal. Nr. 14586.

[13] Žemaitijos žemès teismo aktų (1588) knyga. VUBRS, f. 7, Nr. 303.

[14] Žemaitijos žemès teismo aktų (1589-1590) knyga. VUBRS, f. 7, Nr. 304.

[15] Žemaitijos žemès teismo aktų (1589) knyga. VUBRS, f. 7, Nr. 305.

[16] Žemaitijos žemès teismo aktų (1590) knyga. VUBRS, f. 7, Nr. 306.

[17] Žemaitijos žemès teismo aktų (1590) knyga. VUBRS, f. 7, Nr. 307.

[18] Žemaitijos žemès teismo aktų (1591) knyga. VUBRS, f. 7, Nr. 308.

[19] Žemaitijos žemès teismo aktų (1592) knyga. VUBRS, f. 7, Nr. 309.

[20] Žemaitijos žemès teismo aktų (1592) knyga. VUBRS, f. 7, Nr. 310.

[21] Žemaitijos žemès teismo aktų (1593) knyga. VUBRS, f. 7, Nr. 311.

[22] Žemaitijos žemès teismo aktų (1593) knyga. VUBRS, f. 7, Nr. 312.

[23] Žemaitijos žemès teismo aktų (1595) knyga. VUBRS, f. 7, Nr. 313.

[24] Žemaitijos žemès teismo aktų (1595) knyga. VUBRS, f. 7, Nr. 314.

[25] Žemaitijos žemès teismo aktų (?) knyga. VUBRS, f. 7, Nr. 315.

[26] Žemaitijos žemès teismo aktų (1596) knyga. VUBRS, f. 7, Nr. 316.

[27] Žemaitijos žemès teismo aktų (1596) knyga. VUBRS, f. 7, Nr. 317.

[28] Žemaitijos žemès teismo aktų (1597) knyga. VUBRS, f. 7, Nr. 318.

[29] Žemaitijos žemès teismo aktų (1597) knyga. VUBRS, f. 7, Nr. 319.

[30] Žemaitijos žemès teismo aktų (1597) knyga. VUBRS, f. 7, Nr. 320.

[31] Žemaitijos žemès teismo aktų (1598) knyga. VUBRS, f. 7, Nr. 321.

[32] Žemaitijos žemès teismo aktų (1598) knyga. VUBRS, f. 7, Nr. 322.

[33] Žemaitijos žemès teismo aktų (1599) knyga. VUBRS, f. 7, Nr. 323.

[34] Žemaitijos žemès teismo aktų (1599) knyga. VUBRS, f. 7, Nr. 324.

[35] Žemaitijos žemès teismo aktų (1599) knyga. VUBRS, f. 7, Nr. 325.

[36] Žemaitijos žemès teismo aktų (1600) knyga. VUBRS, f. 7, Nr. 326.

[37] Žemaitijos žemès teismo aktų (1596?) knyga.VUBRS, f. 7, Nr. 327.

[38] Žemaitijos žemès teismo aktų (1600?) knyga. VUBRS, f. 7, Nr. 328.

[39] Žemaitijos žemès teismo bylų (1590) knyga. VUBRS, f. 7, Nr. 364 (ŽŽB-3).

[40] Žemaitijos žemès teismo bylų (1590) knyga. VUBRS, f. 7, Nr. 365 (ŽŽB-4).

[41] Žemaitijos žemès teismo bylų (1591-1592) knyga. VUBRS, f. 7, Nr. 366 (ŽŽŻ-5).

[42] Žemaitijos žemès teismo bylų (1592) knyga. VUBRS, f. 7, Nr. 367 (ŽŽB-6).

[43] Žemaitijos žemès teismo bylų (1592) knyga. VUBRS, f. 7, Nr. 368 (ŽŽB-7).

[44] Žemaitijos žemès teismo bylų (1592) knyga. VUBRS, f. 7, Nr. 369 (ŽŽB-8).

[45] Žemaitijos žemès teismo bylų (1593) knyga. VUBRS, f. 7, Nr. 370 (ŽŽB-9).

[46] Žemaitijos žemès teismo bylų (1593) knyga. VUBRS, f. 7, Nr. 371 (ŽŽB-10).

[47] Žemaitijos žemès teismo bylų (1593) knyga. VUBRS, f. 7, Nr. 372 (ŽŽ̉-11).

[48] Žemaitijos žemès teismo bylų (1593) knyga.VUBRS, f. 7, Nr. 373 (ŽŽB-12).

[49] Žemaitijos žemès teismo bylų (1594) knyga. VUBRS, f. 7, Nr. 374 (ŽŽB-13).

[50] Žemaitijos žemès teismo bylų (1594) knyga. VUBRS, f. 7, Nr. 375 (ŽŽB-14).

[51] Žemaitijos žemès teismo bylų (1595) knyga. VUBRS, f. 7, Nr. 376 (ŽŽ̉-15).

[52] Žemaitijos žemès teismo bylų (1595) knyga. VUBRS, f. 7, Nr. 377 (ŽŽB-16).

[53] Žemaitijos žemès teismo bylų (1595) knyga. VUBRS, f. 7, Nr. 378 (ŽŽB-17).

[54] Žemaitijos žemès teismo bylų (1595) knyga.VUBRS, f. 7, Nr. 379 (ŽŽB-17a). 
[55] Žemaitijos žemès teismo bylų (1596) knyga. VUBRS, f. 7, Nr. 380 (ŽŽB-18).

[56] Žemaitijos žemès teismo bylų (1595?) knyga. VUBRS, f. 7, Nr. 381 (ŽŽB-19).

[57] Žemaitijos žemés teismo bylų (1597) knyga. VUBRS, f. 7, Nr. 382 (ŽŽB-19).

[58] Žemaitijos žemès teismo bylų (1597) knyga. VUBRS, f. 7, Nr. 383 (ŽŽB-20).

[59] Žemaitijos žemès teismo bylų (1597) knyga. VUBRS, f. 7, Nr. 384 (ŽŽB-21).

[60] Žemaitijos žemès teismo bylų (1597) knyga. VUBRS, f. 7, Nr. 385 (ŽŽB-22).

[61] Žemaitijos žemès teismo bylų (1597) knyga. VUBRS, f. 7, Nr. 386 (ŽŽB-23).

[62] Žemaitijos žemès teismo bylų (1597) knyga. VUBRS, f. 7, Nr. 387 (ŽŽB-24).

[63] Žemaitijos žemès teismo bylų (1598) knyga. VUBRS, f. 7, Nr. 388 (ŽŽB-25).

[64] Žemaitijos žemès teismo bylų (1599) knyga. VUBRS, f. 7, Nr. 390 (ŽŽB-[29]).

[65] Žemaitijos žemès teismo bylų (1599) knyga. VUBRS, f. 7, Nr. 391 (ŽŽB-27).

[66] Žemaitijos žemès teismo bylų (1599) knyga. VUBRS, f. 7, Nr. 392 (ŽŽB-28).

[67] Žemaitijos žemès teismo bylų (1599) knyga. VUBRS, f. 7, Nr. 393 (ŽŽB-29).

[68] Žemaitijos žemès teismo bylų (1599) knyga. VUBRS, f. 7, Nr. 394 (ŽŽB-30).

[69] Žemaitijos žemès teismo bylų (1600) knyga. VUBRS, f. 7, Nr. 395 (ŽŽB-31).

[70] Žemaitijos žemès teismo bylų (1600) knyga. VUBRS, f. 7, Nr. 396 (ŽŽB-32).

[71] Žemaitijos žemès teismo bylų (1600) knyga. VUBRS, f. 7, Nr. 397 (ŽŽB-[33,38]).

[72] Žemaitijos žemès teismo bylų (1600) knyga. VUBRS, f. 7, Nr. 398 (ŽŽB-34).

[73] EITMAITYTĖ, Elena. Vytauto Didžiojo universiteto Rankraščių skyrius. Bibliografijos žinios, Nr. 1(49), 1936, p. 27-30.

[74] DRUNGILAS, Jonas. Etnosocialinis mobilumas Lietuvos Didžiojoje Kunigaikštystejje: Gruževskių giminès pavyzdys (XVI a. antroji pusè - XVIII a. pradžia). Lietuvos istorijos metraštis, 2004, 2. Vilnius, 2005, p. 53-78.

[75] GORODECKAS, Eduardas. Žemès teismo genezès Lietuvos Didžiojoje Kunigaikštystėje klausimu. Ǐ̌: Jaunujju istorikų darbai. Respublikinés jaunųų istorikų mokslinès konferencijos tezės. $1980 \mathrm{~m}$. gegužè. Trečioji knyga. Vilnius, 1980, p. 116-119.

[76] SAVIŠČEVAS, Eugenijus. Žemaitijos savivalda ir valdžios elitas 1409-1566 metais. Vilnius, 2010.

[77] TRIMONIENĖ, Rita Regina. Bajorų luomo vedybinių ryšių atspindžiai Žemaičių žemès ir pilies teismo aktuose. XVI a. II pusè - XVII a. pirma pusé. Iš: Istoriniai tekstai ir vietos kultūra. Šiauliai-Ryga, 2004, p. 167-178.

[78] VILIMAS, Darius. Lietuvos Didžiosios Kunigaikštystès žemés teismo sistemos formavimasis (1564-1588). Vilnius, 2006.

[79] VILIMAS, Darius. LDK pavieto žemės teismų funkcija - tarp notariato ir teismo (iki $1588 \mathrm{~m}$.) (lietuviškų pavietų atvejis). Lituanistica, 2011, Nr. 4(86), p. 355-364.

[80] VILIMAS, Darius. Kauno žemès teismas paskutiniais Stepono Batoro valdymo metais (tematinio tyrimo metmenys). Lituanistica, 2011, Nr. 3(85), p. 227-242.

[81] VILIMAS, Darius. Teisminès kultūros atspindžiai Kauno pavieto žemės teismuose XVI a. devintajame dešimtmetyje. Iš: Lietuvos Didžiosios Kunigaikštystès istorijos kraštovaizdis. Mokslinių straipsnių rinkinys, skirtas prof. J. Kiaupienès 65-mečiui. Vilnius, 2012, p. 503-524.

[82] VILIMAS, Darius. Seniausios Lietuvos Didžiosios Kunigaikštystės žemės teismų knygos (iki 1589 m.) Lietuvos Respublikos archyvuose. Iš: Lietuvos Metrika. 1991-1996 metu tyrinéjimai. Sud. Z. Kiaupa, A. Urbanavičius. Vilnius, 1998, p. 238-254.

[83] VILIMAS, Darius. Upytės pavieto žemès teismo elitas ir žemès teismo kasdienybè (15661588). Iš: Iš Panevėžio praeities. Upytès žemei 750 metų. Konferencijos pranešimai, Panevėžys, 200409 14. Panevėžys, 2004, p. 70-91. 
[84] Акты, издаваемые Виленскою археографическою коммиссиею для разбора древних актов. Т. 1-39. Вильна, 1865-1914.

[85] Каталог древним актовым книгам губерний: Виленской, Гродненской, Минской и Ковенской, также книгам некоторых судов губерний Могилевской и Смоленской, хранящимся ныне в Центральном архиве в Вильне. Сост. М. Горбачевский. Вильна, 1872.

[86] Опись документов Виленского Центрального Архива древних актовых книг. Выпуски I-V. Вильна, 1901-1907.

[87] ПОЛИЩУК, Володимир. Между процедурой и формуляром: источниковедческий анализ судебных записей замковых книг перед реформой 1564-1566 гг. (на примере луцких замковых книг 1558-1566 гг.). Iš: Lietuvos Didžiosios Kunigaikštystès istorijos šaltiniai. Faktas. Kontekstas. Interpretacija. Vilnius: LII 1-kla, 2007, p. 355-380.

[88] ПОЛІЩУК, Володимир. Луцький замковий уряд в адмінистративній системі Великого князівства Литовского до реформ 1564-1566 рр. Украӥньский історичний журнал. Київ, 2003. № 2, с. 3-13; 2005, № 1, с. 108-124.

[89] РАДАМАН, Андрэй. Арганізацыя и склад полацкога земскага суда ў другой палове XVI - першай трэці XVII ст. ГЕРОЛД-LITHERLAND. № 18. Горадня-Менск, 2011, с. 21-36.

[90] СТАРЧЕНКО, Наталія. Вбиство князів Четвертинских 1576 р.: судовий процес та замиреня на Волини в кинці XVI ст. СОЦІУМ. Альманах соціальної історїі, 2007, випуск 7, с. 83110.

[91] СТАРЧЕНКО, Наталія. Судова реторика як вияв цінностей волинскої шляхти кінця 16 ст. (на приклади справи про вбивство Балтазара Гнівоша з Олексова). СОЦІУМ. Альманах соціальної исторїі, 2010, випуск 9, с. 318-360.

DARIUS VILIMAS

\section{Samogitian Nobles in the Land Court at the end of the 16th century (A brief review of the former and surviving Samogitian Land Court Books)}

Summary

The surviving manuscript court books are the main source for the study of the life of the nobility of the Grand Duchy of Lithuania in district land courts at the end of the 16th century. A series of Samogitian land court books is especially interesting because they come in an almost uninterrupted flow throughout the final quarter of the century, and even though the books are in a very different state of preservation, they are probably the largest ones (next to Grodno and Slonim district land court books). However, the research possibility itself is disturbed by two circumstances. First of all, the books were rebound during the 20th century; therefore, the descriptions of their contents made (and published) in the beginning of the century are not consistent with the present situation. However, most importantly, after the "reformation" of the collection of books into the books of deeds and cases, the analysis of court records, in the attempt to group them into notarial and judicial records, is made 
rather complicated. The article addresses the oldest extant (up to 1600) Samogitian land court books, their state of preservation, contents and thematic structure. Attempts are made to compare the scope and contents of land court books; the books reported lost, divided or merged together are indicated. It has been determined that starting from the final decade of the 16th century the Samogitian land court kept the land court books of deeds, current affairs and judicial proceedings. Hence, from this period onwards we can already speak about the existence of three microchancelleries in the land court.

Key words: thematic structure of land court books of the Grand Duchy of Lithuania, Samogitian land court manuscript books, Ivanas Sprogis, the Second Statute of the Grand Duchy of Lithuania, the nobility of the Grand Duchy of Lithuania 